\title{
SCHEDULING LINEAR CONSTRUCTION PROJECTS WITH CONSTRAINTS ON RESOURCE AVAILABILITY
}

\author{
S. BIRUK ${ }^{1}$, P. JAŚKOWSKI ${ }^{2}$
}

\begin{abstract}
Production rates for various activities and overall construction project duration are significantly influenced by crew formation. Crews are composed of available renewable resources. Construction companies tend to reduce the number of permanent employees, which reduces fixed costs, but at the same time limits production capacity. Therefore, construction project planning must be carried out by means of scheduling methods which allow for resource constrains. Authors create a mathematical model for optimized scheduling of linear construction projects with consideration of resources and work continuity constraints. Proposed approach enables user to select optimal crew formation under limited resource supply. This minimizes project duration and improves renewable resource utilization in construction linear projects. This paper presents mixed integer linear programming to model this problem and uses a case study to illustrate it.
\end{abstract}

Keywords: construction project management, linear project scheduling, resource allocation

\section{INTRODUCTION}

The construction industry adopted and developed many methods of scheduling construction projects. The traditional bar charts show duration, start and finish dates for activities in a simple way - without relationships between them. The most popular method, developed in the early 1960s, is the Critical Path Method (CPM). This mathematical calculation allows users to determine the critical (longest) path, the start and finish dates, and the floats of activities. This method proved useful, so its extensions to incorporate resource analysis to the model to facilitate resource

\footnotetext{
${ }^{1}$ PhD., Eng., Lublin University of Technology, Faculty of Civil Engineering and Architecture, Nadbystrzycka str. 40 , 20-618 Lublin, Poland, e-mail: s.biruk@pollub.pl

${ }^{2}$ DSc., PhD., Eng., Lublin University of Technology, Faculty of Civil Engineering and Architecture, Nadbystrzycka str. 40, 20-618 Lublin, Poland, e-mail: p.jaskowski@pollub.pl
} 
assignment and levelling are constantly developed by researchers and practitioners. However, in the case of linear projects, such as construction of highways, railways, tunnels, or pipelines, the CPM is of limited applicability.

Linear projects consist of work repeated many times in consecutive locations (units or sections of the facility) by specialized crews [10]. The specific character of each linear project resulted in the emergence and development of new planning techniques, e.g. Linear Scheduling Method (LSM), based on a time-versus-distance (location) diagrams.

The LSM is focused on work continuity. The effort made towards assuring continuity of crews' work is expected to make the best use of the learning effect, to minimize idle time and to improve construction equipment utilization rates, but at the same time it can lead to longer duration of the entire project. Sellinger [18] believes that the introduction of certain discontinuities in the workflow can result in reduction of project duration. Therefore, a trade-off problem between idle time and project duration should be considered while allocating resources for linear projects [15]. Another issue is the availability of resources. It is usually limited, and the limits affect the project duration. Thus, in the course of project planning, resource availability and levelling should be taken into account [5].

The literature on the subject provides insight into the ideas for combining advantages of the CPM and the LSM. Harmelink and Rowings [8] identify a set of controlling activities, by analogy to the CPM method. Polish research developed time coupling methods (TCM) to solve the repetitive and linear scheduling problems in construction $[2,9,17]$. TCMs base specific relations of the start and completion dates of individual jobs completed on particular units. The TCM can be classified as a special case of the permutation flow shop scheduling problem [16].

Mattila and Abraham [14] presented a method of resource allocation for linear projects that uses the idea of a controlling path, assuming that resource allocation can be controlled by changing the crews' productivity rates for processes that are outside the controlling path. They propose a binary linear programming model of this problem, and solve it using off-the-shelf software (LINDO).

This same problem was analysed by Georgy [7]. He used a genetic algorithm for solving this problem. Because of the graphical nature of the LSM, the author used AutoCADTM and AutoLISP programming languages to provide a tool for scheduling resources for linear projects.

El-Gafy [5] analysed the possibility of using Ant Colony Optimization (ACO) in aim of minimizing the total duration of linear projects and day-to-day fluctuation of resource usage (including resource level constraints). It was assumed that the amount of resources assigned to a task can vary from location to location. Chen and Shahandashti [4] used simulated annealing procedure for the same 
problem. Solving this type of problem usually requires long computing time to identify the global optimum. Therefore, the resource levelling and resource allocation problems usually cannot be formulated as linear programming problems without additional simplifying assumptions. El-Rayes and Moselhi [6] developed a two-step iterative algorithm for linear projects, planning to minimize the crews' idle times, at the same time taking into account their limited availability at fixed-time windows. This limitation is particularly important if the contractor performs work simultaneously at several construction sites. Work on a specific section can be performed by one of the available crews whose labour productivities are different.

In many cases, the same resources can be used for projects carried out in parallel. Chen and Shahandashti [3] presented a procedure for resource allocation in multi-project linear scheduling. The goal was defined as minimizing the sum of weighted project durations and the fluctuation of the day-to-day usage of resources. The solution is to be visible in two stages. In the first stage, the feasible resource assignment is determined under the assumption that the projects were carried out independently. In the second stage, amounts of resources allocated to various activities is changed, and a simulated annealing procedure is adopted to find the optimal solution.

Marcinkowski [13] formulated a model of allocating a hierarchical structure for work performed on separated work fronts. This model enables an automated calculation aimed at designating a contractor for the set of tasks to be executed on the work fronts, based on their labor consumption and referred to resources of any of the levels of a hierarchical structure.

The problem of crew formation and subcontracting in completing linear projects was studied by Liu and Wang [12]. The number of additional resources was limited. Allocation of outsourced resources is one possibility of accelerating a project. The model proposed by the authors minimized either total project duration, or total interruption time. If supplemented with cost information (indirect and direct costs, including cost of outsourced resources), it allows the construction manager to make a decision about allocating additional resources. The proposed model was solved using a constraint programming $(\mathrm{CP})$ approach.

Bakry et al. [1] discussed strategies of accelerating linear projects and elaborated on algorithms of allocating additional resources based on the lowest cost slope and the criticality of activity. The algorithm can be implemented in spreadsheet software.

The rapid development of computerization and its implementation to project management led to great interest of academics and practitioners of computer methods aiding linear project planning (e.g. Planista software in Poland). Due to the computational complexity of scheduling algorithms for linear projects (including resource limitations), heuristic and metaheuristic algorithms which use 
specified modelling techniques are developed. The existing approaches consider a variety of constraints and optimization objectives, mainly not mathematically formalized. Therefore, in the next section the authors present the original mathematical model of the problem of renewable resource allocation, with consideration of work continuity constraints and different order of units on which processes are realized. The developed model can be solved using commonly known linear programming software.

\section{MATHEMATICAL PROBLEM FORMALIZATION}

A linear project (road, tunnel, pipeline etc.) should be divided into sections (working units) defined by different length and work labour intensity. Repeatable processes from the set $I=\{1,2, \ldots, n\}$ are to be conducted in each of these units $j(j \in J, J=\{1,2, \ldots, m\})$.. For each type $i(i \in I)$ of process, a separate working crew or set of machines is to be provided, and the composition of these crews / machine sets is to remain constant. For each unit $j$, a directed graph $G_{j}=\left\langle I, A_{j}\right\rangle$ with one start and one finish node is to be defined: $I=\left\{1,2, \ldots, n_{j}\right\}$ there is a set of graph nodes (identical to a set of processes types), and $A_{j} \subset I \times I$ there is a set of arcs (the precedence relations between the processes) linking the graph nodes.

The precedence relations between processes in each unit are of finish-to-start type with time lags: process $b$ can start after finishing its direct predecessor $a$, but not earlier than after $f_{a, b}$ days.

The order of units where a process is successively performed is defined as a permutation $\pi_{i}(j)=c_{i, j}$; it is defined for each unit.

The work in a unit progresses according to previously made arrangements (according to the mileage or from the end of the section to the beginning). The order of units, due to the adopted method of mathematical formalization, must be specified also in the case when a specific process in not realized in this unit. The accepted order does not affect the obtained optimization solution.

To complete each process, renewable resources (e.g. the workers of various specialities, machines) need to be available. The set of all resource types is denoted by $R$.

For each process $i$, a set $W_{i}$ of crew formation or machine sets options, called later crew modes, can be defined. Each crew mode $w \in W_{i}, \forall i \in I$, is characterized by a different number $z_{i, r, w}$ of renewable resource units $r$ from the $R$ set, included in the project. Throughout the planning period, the number of available resource units $r(\forall r \in R)$ is equal to $Z_{r}$. 
The choice of crew mode is modelled by means of a binary variable $x_{i, w} \in\{0,1\}$. The variable $x_{i, w}$ equals 1 if the process type will be realized by a crew organized using this mode $w \in W_{i}$, and equals 0 in other cases. Based on unit labour intensity and crew productivity, a duration $t_{i, j, w}$ can be defined for each process $i$ to be conducted at each unit $j$ for each crew mode $w \in W_{i}$. If a particular process is not realized at a specific unit, we assume that its duration is 0 (for all crew modes). A variable determining the realization time of process $i$ at unit $j$ is $t_{i, j}$. To assure that the resource demand does not exceed supply, an additional binary variable $y_{i, t}(\forall i \in I, t=1,2, \ldots, H$, where $H$ - planning horizon) is introduced. If the process $i$ is realized in day $t$, this variable assumes the value of 1 , and it equals 0 otherwise.

The optimal set of crew formations (optimal values of decision variables $x_{i, w}$ ) and process start times $s_{i, j}$ at the consecutive units, for which project duration $T$ is minimal, can be determined by solving a mathematical model of the following form:

$$
\begin{gathered}
\min z: \quad z=T, \\
s_{1, j}=0, j: c_{1, j}=1, \\
s_{i, j}+t_{i, j} \leq T, \forall i \in I, j: c_{n, j}=m, \\
t_{i, j}=\sum_{w \in W_{i}} t_{i, j, w} \cdot x_{i, w}, \forall i \in I, \forall j \in J, \\
s_{b, j}-s_{a, j} \geq f_{a, b}, \quad \forall(a, b) \in A_{j} \text { and the same progress of works, } \forall j \in J, \\
s_{b, j}+t_{b, j}-s_{a, j}-t_{a, j} \geq f_{a, b}, \forall(a, b) \in A_{j} \text { and the same progress of works, } \forall j \in J, \\
s_{b, j}-s_{a, j}-t_{a, j} \geq f_{a, b}, \forall(a, b) \in A_{j} \text { and the oppositeprogress of works, } \forall j \in J, \\
s_{i, l}=s_{i, k}+t_{i, k}, \forall i \in I, \forall(k, l): k, l \in J \wedge c_{i, l}=c_{i, k}+1, \\
\sum_{t=1}^{H} y_{i, t}=\sum_{j \in J} t_{i, j}, \forall i \in I, \\
\sum_{i, j}+t_{i, j} \geq t \cdot y_{i, t}, \quad \forall i \in I, j: c_{i, j}=m, t=1,2, \ldots, H, \\
\sum_{i \in I} \sum_{w \in W_{i}} z_{i, r, w} \cdot x_{i, w} \cdot y_{i, t} \leq Z, \forall r \in R, t=1,2, \ldots, H, \\
\sum_{w \in W_{i}} x_{i, w}=1, \forall i \in I,
\end{gathered}
$$




$$
\begin{gathered}
y_{i, t} \in\{0,1\}, \forall i \in I, t=1,2, \ldots, H, \\
x_{i, w} \in\{0,1\}, \forall i \in I, \forall w \in W_{i}, \\
s_{i, j} \geq 0, \quad \forall i \in I, \quad \forall j \in J .
\end{gathered}
$$

The objective function (2.1) minimizes project duration. The first process on the first unit, on which it will be performed, starts at date 0 (relation (2.2)). Each process must be completed in each unit no later than at a predefined deadline - according to inequality (2.3). Equation (2.4) describes how to calculate the duration of each process at each unit.

Process start dates at particular units are calculated according to equations (2.5) - (2.8). This way, one accounts for precedence relations, defined construction progress on units, possible time lags, and the order of units (given in the form of a permutation for each process). Fulfilment of the conditions (2.8) and (2.9) ensures the crews' work continuity.

The number of days taken up by a particular process is equal to the time of this process' execution at all units (dependence (2.9)). Conditions (2.10) and (2.11) allow the planner to define start and finish dates of processes on the basis of $y_{i, t}$ variables values. According to equation (2.12), resource demand cannot exceed the limit of their availability at any day of the project. Only one crew formation mode can be chosen for a process regardless of the place of its execution (unit) according to the equation (2.13). The variables must also meet the constraints $(2.14)-(2.16)$.

In the case of simple practical problems, the above model can be solved with popular solvers with non-linear add-ons. The relationship (2.12) can be reduced to a linear form by implementing additional binary variables:

$$
v_{i, w, t}=x_{i, w} \cdot y_{i, t}, \forall i \in I, \forall w \in W_{i}, t=1,2, \ldots, H,
$$

with additional limitations:

$$
\begin{gathered}
v_{i, w, t} \leq x_{i, w}, \quad \forall i \in I, \forall w \in W_{i}, t=1,2, \ldots, H, \\
v_{i, w, t} \leq y_{i, t}, \quad \forall i \in I, \forall w \in W_{i}, t=1,2, \ldots, H, \\
x_{i, w}+y_{i, t}-v_{i, w, t} \leq 1, \quad \forall i \in I, \forall w \in W_{i}, t=1,2, \ldots, H, \\
v_{i, w, t} \in\{0,1\}, \quad \forall i \in I, \quad \forall w \in W_{i}, t=1,2, \ldots, H .
\end{gathered}
$$




\section{EXAMPLE}

Table 1 summarizes data concerning precedence relations of processes carried out at three unit (sections) of a notional linear project. The data present is enough to create activity-on-node graphs, the same for each section, that model dependencies between processes. Processes at different sections are carried out starting from section one - the exception is the third process whose execution starts at the end point of section 3 and finishes at the beginning of section 1 (according to permutation given in Table 1).

Table 1. The precedence relations among processes in the example linear project

\begin{tabular}{|c|c|c|c|c|c|}
\hline \multirow{2}{*}{$\begin{array}{c}\text { Process } \\
a\end{array}$} & \multirow{2}{*}{ Predecessors } & \multirow{2}{*}{$\begin{array}{c}f_{a, b} \\
\text { [days] }\end{array}$} & \multicolumn{4}{|c|}{ Units permutation } \\
\cline { 3 - 6 } & & & $j=1$ & $j=2$ & $j=3$ \\
\hline 1 & - & - & 1 & 2 & 3 \\
\hline 2 & 1 & 3 & 1 & 2 & 3 \\
\hline 3 & 1 & 1 & 3 & 2 & 1 \\
\hline 4 & 2 & 10 & 1 & 2 & 3 \\
\hline \multirow{2}{*}{5} & 3 & 0 & 1 & 2 & 3 \\
\cline { 2 - 3 } & 4 & 10 & & & \\
\hline
\end{tabular}

Tables 2 and 3 list further input: process durations and renewable resources demand three feasible crew formation modes. Each day there are 4 units of a resource $r=1$ and 5 units of resource $r=2$ available.

Table 2. Durations $t_{i, j, w}$ of processes on particular units for analysed crew formation modes (example) [days]

\begin{tabular}{|c|c|c|c|c|c|c|c|c|c|}
\hline \multirow{2}{*}{$\begin{array}{c}\text { Process } \\
i\end{array}$} & \multicolumn{3}{|c|}{ Crew formation mode: } \\
\cline { 2 - 12 } & $j=1$ & $j=2$ & $j=3$ & $j=1$ & $j=2$ & $j=3$ & $j=1$ & $j=2$ & $j=3$ \\
\cline { 2 - 11 } & 3 & 3 & 3 & 2 & 2 & 2 & 4 & 4 & 4 \\
\hline 1 & 3 & 4 & 3 & 2 & 3 & 2 & 4 & 5 & 4 \\
\hline 2 & 2 & 2 & 2 & 1 & 2 & 1 & 3 & 3 & 3 \\
\hline 3 & 3 & 4 & 3 & 2 & 2 & 2 & 4 & 4 & 4 \\
\hline 4 & 4 & 3 & 2 & 3 & 2 & 4 & 5 & 4 \\
\hline 5 & & & & & & & & & \\
\hline
\end{tabular}


Table 3. Demands $z_{i, r, w}$ on two types of resources to carry out particular processes (example) [units]

\begin{tabular}{|c|c|c|c|c|c|c|}
\hline \multirow{2}{*}{$\begin{array}{c}\text { Process } \\
i\end{array}$} & \multicolumn{2}{|c|}{$w=1$} & \multicolumn{2}{c|}{$w=2$} & \multicolumn{2}{c|}{$w=3$} \\
\cline { 2 - 7 } & $r=1$ & $r=2$ & $r=1$ & $r=2$ & $r=1$ & $r=2$ \\
\hline 1 & 2 & 2 & 3 & 3 & 1 & 1 \\
\hline 2 & 2 & 2 & 3 & 2 & 2 & 1 \\
\hline 3 & 3 & 2 & 3 & 4 & 1 & 2 \\
\hline 4 & 3 & 4 & 5 & 4 & 3 & 3 \\
\hline 5 & 0 & 2 & 2 & 2 & 1 & 1 \\
\hline
\end{tabular}

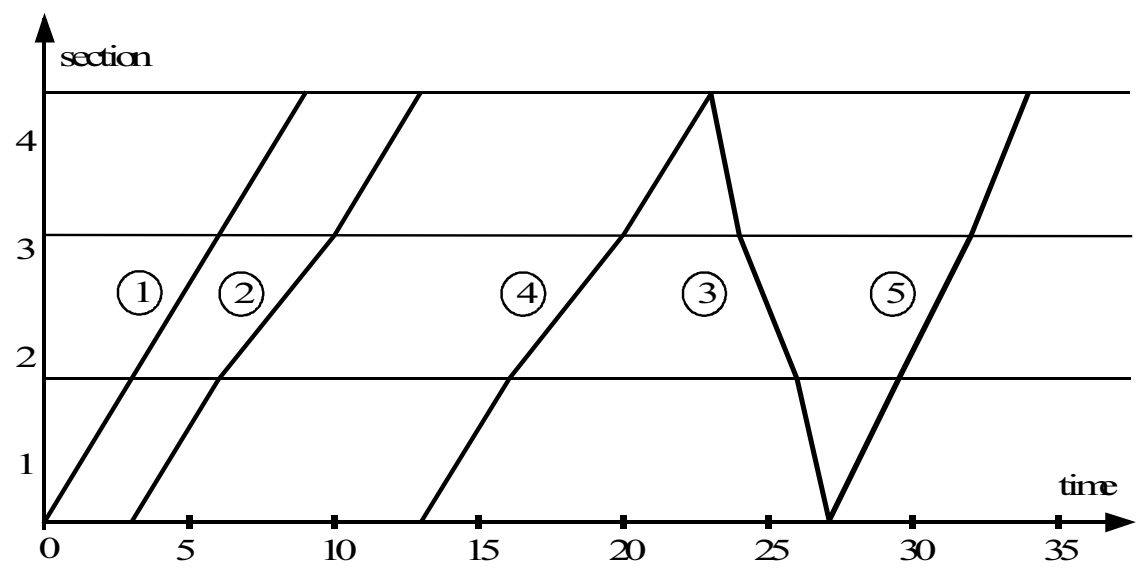

Fig. 1. Project schedule, example (resources availability level not exceeded)

The mathematical model in the example was solved using Lingo 14.0. Fig. 1 shows the project schedule in the form of a time-versus-distance diagram that meets the resource availability constraints.

The project duration is 34 days. Processes 1 and 4 are carried out by crew organized according to mode 1 , while all the other processes by crews organized according to mode 2 .

Fig. 2 shows the project schedule with unlimited availability of resources with minimal project duration of 31 days. All crews are organized according to mode 2 for all processes. Process 3, with non-zero total float time, can start between day 8 and day 21 (early start date is 7, late start date is 20). 


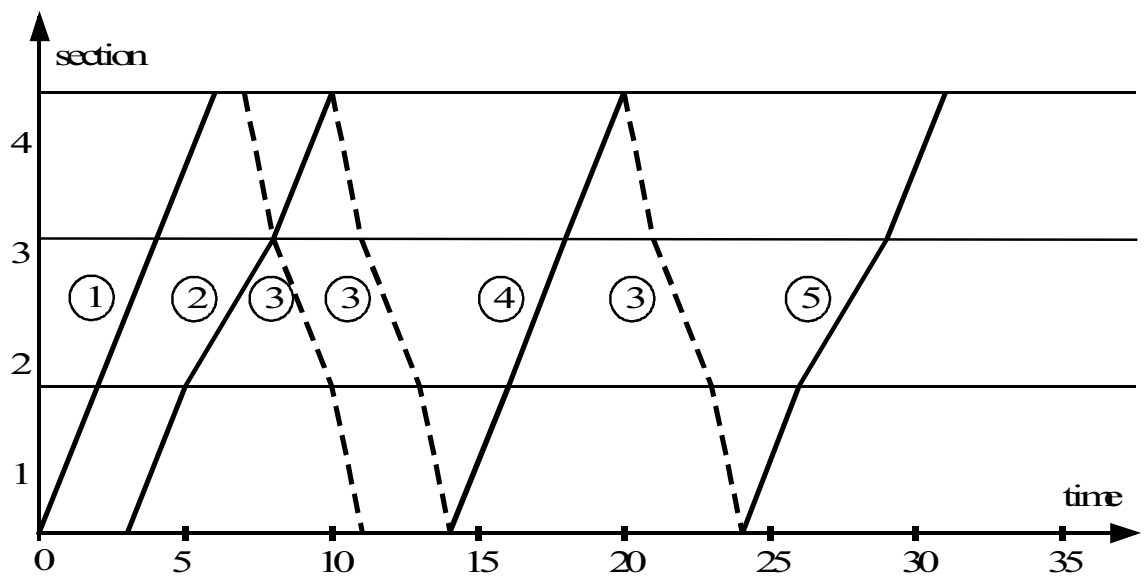

Fig. 2. Project schedule without resource availability limitations (example)

\section{CONCLUSIONS}

Scheduling repetitive activities in linear projects means not only defining their duration, but also providing proper crew formulation and resource utilization. Reducing project duration implies measurable benefits like early completion bonuses for contractors and opportunities to enter the operating phase earlier - for the client. This provides rationale for the search of better planning techniques using, in particular, exact and heuristic methods to solve combinatorial linear project scheduling problems with resources availability constraints.

The methods of schedule optimisation presented in existing literature usually require knowledge of general purpose programming or specialized programming languages. The practical application of many formulations is limited due to computational complexity.

The proposed model allows the user to find optimal allocation of limited renewable resources (crews, construction equipment) in linear projects. The goal of optimization is minimizing the overall project duration. The model considers permutations of sequences of sections at which processes are performed. This can prove useful e.g. in modelling work realized in different directions on a time-versus-distance (location) diagram. Linear projects that comprise small number of activities involving few resource types can be optimized by means of popular solvers with mixed integer linear or non-linear programming options.

Further research will focus on including other conditions and constraints typical for linear construction projects, e.g. the learning curve, the possibility of subcontracting or splitting activities, and objectives used in project management and for bids selection [11]. To solve more complex, 
real-life scheduling problems within reasonable time and with less computational effort, the authors are going to develop metaheuristic procedures.

\section{ACKNOWLEDGMENTS}

This work was financially supported by Ministry of Science and Higher Education in Poland within the statutory research number $\mathrm{S} / 63 / 2016$.

\section{REFERENCES}

1. I. Bakry, O. Moselhi, T. Zayed T., "Optimized acceleration of repetitive construction projects", Automation in Construction 39: 145-151, 2014.

2. W. Bożejko, Z. Hejducki, Z., M. Wodecki, "Applying metaheuristic strategies in construction projects management”, Journal of Civil Engineering and Management 18(5): 621-630, 2012.

3. P. H. Chen, S. M. Shahandashti, S.M., "Simulated Annealing Algorithm for Optimizing Multi-Project Linear Scheduling with Multiple Resource Constraints", Proceedings of 24th International Symposium on Automation and Robotics in Construction (ISARC 2007), September 19-21, Kochi, India, 429-434, 2007.

4. P. H. Chen, S. M. Shahandashti, "Modified Simulated Annealing Algorithm and Modified Two-Stage Solution Finding Procedure for Optimizing Linear Scheduling Projects with Multiple Resource Constraints", Proceedings of 24th International Symposium on Automation and Robotics in Construction (ISARC 2007), September 19-21, Kochi, India, 411-416, 2007.

5. M. El-Gafy, "Resource Allocation for Repetitive Construction Schedules: An Ant Colony Optimization Approach", Proceedings of the ASC 43rd Annual International Conference, Flagstaff, Arizona, 2007.

6. K. El-Rayes, O. Moselhi, "Resource-Driven Scheduling of Repetitive Activities", Construction Management and Economics 16(4): 433-446, 1998.

7. M. E. Georgy, M.E., "Evolutionary Resource Schedule for Linear Project", Automation in Construction 17: 573-583, 2008.

8. D. J. Harmelink, J. E. Rowings, "Linear Scheduling Model: Development of Controlling Activity Path", Journal of Construction Engineering and Management 124(4): 263-268, 1998.

9. Z. Hejducki, M. Rogalska, M., "Time coupling methods: construction scheduling and time/cost optimization", Oficyna Wydawnicza Politechniki Wrocławskiej, Wrocław, 2011.

10. M. Krzemiński., "Construction scheduling and stability of the resulting schedules", Archives of Civil Engineering LXII(3): 89-100, 2016.

11. M. Książek, P. Ciechowicz, "Selection of the General Contractor using the AHP method", Archives of Civil Engineering LXII(3): 105-116, 2016.

12. S.-S. Liu, C.-J. Wang, "Optimization Model for Resource Assignment Problems of Linear Construction Project", Automation in Construction 16: 460-473, 2007.

13. R. Marcinkowski, "Complex-structure resource management in engineer and construction operations", Archives of Civil Engineering 49(1): 63-77, 2003.

14. K. G. Mattila, D. M. Abraham, "Resource Leveling of Linear Schedules Using Integer Linear Programming", Journal of Construction Engineering and Management 12(3): 232-244, 1998.

15. K. Nassar, "Evolutionary Optimization of Resource Allocation in Repetitive Construction Schedules", ITcon 10: 265-273, 2005.

16. M. Podolski, "Scheduling of multiunit projects using tabu search algorithm", Journal of Science of the gen. Tadeusz Kosciuszko Military Academy of Land Forces 1: 110-122, 2015.

17. M. Rogalska, W. Bożejko, Z. Hejducki, "Time/cost optimization using hybrid evolutionary algorithm in construction project scheduling", Automation in Construction 18(1): 24-31, 2008.

18. S. Selinger, S. "Construction Planning for Linear Projects”, Journal of Construction Division 106(CO2): 195$205,1980$. 


\section{LIST OF FIGURES AND TABLES:}

Fig. 1. Project schedule, example (resources availability level not exceeded)

Rys. 1. Harmonogram realizacji przedsięwzięcia, przykład (nieprzekroczony poziom dostępności zasobów)

Fig. 2. Project schedule without resources availability limitations (example)

Rys. 2. Harmonogram realizacji przedsięwzięcia bez uwzględnienia ograniczeń w dostępności zasobów

Tab. 1. The precedence relations among processes in the example linear project

Tab. 1. Relacje kolejnościowe między procesami przy realizacji obiektu liniowego w przykładzie

Tab. 2. Durations $t_{i, j, w}$ of processes on particular units for analysed crew formation modes (example) [days]

Tab. 2. Czasy $t_{i, j, w}$ wykonania procesów na poszczególnych działkach dla analizowanych wariantów organizacji brygad (przykład) [dni]

Tab. 3. Demands $z_{i, r, w}$ on two types of resources to carry out particular processes modes (example) [units]

Tab. 3. Zapotrzebowanie $z_{i, r, w}$ na dwa rodzaje zasobów do wykonania poszczególnych procesów [szt.] 


\section{HARMONOGRAMOWANIE REALIZACJI OBIEKTÓW LINIOWYCH Z OGRANICZONĄ DOSTĘPNOŚCIĄ ZASOBÓW}

Słowa kluczowe: zarządzanie przedsięwzięciem budowlanym, harmonogramowanie realizacji obiektów liniowych, alokacja zasobów

\section{STRESZCZENIE:}

Przedsięwzięcia budowlane o charakterze liniowym (takie jak budowa autostrad, dróg kolejowych, tuneli czy rurociągów) składają się $\mathrm{z}$ czynności powtarzanych na działkach roboczych. Istotną częścią procesu harmonogramowania przedsięwzięć budowlanych jest dobór zasobów i synchronizacja ich pracy. Liczba przypisanych pracowników lub rodzaj i liczba maszyn budowlanych wpływa na czas wykonania procesów powtarzanych na kolejnych lokalizacjach i w konsekwencji na czas realizacji całego przedsięwzięcia.

Ze względu na obecną recesją gospodarczą, która powoduje trudności w pozyskiwaniu nowych zleceń oraz rosnące koszty pracy, wiele przedsiębiorstw budowlanych redukuje swój potencjał kadrowy. Stąd też istnieje konieczność udoskonalenia metod planowania uwzględniających ograniczoną dostępność kluczowych zasobów. Harmonogramowanie z uwzględnieniem ograniczonej dostępności zasobów, w szczególności brygad specjalizowanych i maszyn, stanowi problem decyzyjny rozwiązywany w przypadku większości przedsięwzięć budowlanych.

Tradycyjnie stosowane w budownictwie harmonogramy belkowe odwzorowują czas, terminy rozpoczynania i zakończenia procesów w prosty sposób - bez zobrazowania zależności technologiczno-organizacyjnych. Najbardziej popularną metodą wspomagającą harmonogramowanie przedsięwzięć budowlanych, z uwzględnieniem relacji kolejnościowych miedzy procesami, jest metoda programowania sieciowego Critical Path Method (CPM), opracowana na początku lat 60 -tych. Ma jednak ona ograniczone zastosowanie w przypadku przedsięwzięć liniowych. Specyfika przedsięwzięć liniowych spowodowała powstanie i rozwój nowych metod planowania, np. Linear Scheduling Method (LSM), koncentrujących się na zapewnieniu ciągłości prowadzenia robót. Planowany przebieg realizacji takich przedsięwzięć jest zazwyczaj przedstawiany w formie cyklogramów: harmonogramów o dwóch osiach współrzędnych, z których jedna odwzorowuje czas a jednostki drugiej wskazują lokalizację robót.

Gwałtowny rozwój komputeryzacji i jej wdrożenie do dziedziny zarządzania przedsięwzięciami spowodował wzrost zainteresowania badaczy i praktyków komputerowymi metodami wspomagania planowania przedsięwzięć liniowych. Ze względu na złożoność obliczeniową dokładnych algorytmów harmonogramowania przedsięwzięć liniowych z ograniczoną dostępnością zasobów, są rozwijane algorytmu heurystyczne i metaheurystyczne. Istniejące metody uwzględniają różne ograniczenia i cele optymalizacji. Stosowanie wielu prezentowanych w literaturze metod optymalizacji harmonogramów wymaga znajomości języków programowania ogólnego bądź specjalnego przeznaczenia.

Autorzy opracowali model matematyczny optymalizacji harmonogramowania przedsięwzięć budowlanych uwzględniający ciągłość wykorzystania zasobów i prowadzenia robót. Proponowane ujęcie problemu umożliwia decydentowi dokonanie wyboru optymalnego wariantu organizacji brygady roboczej w warunkach ograniczonej liczby dostępnych pracowników. Model minimalizuje czas trwania przedsięwzięcia i zwiększa stopień wykorzystania zasobów w czasie realizacji przedsięwzięć budowlanych o charakterze liniowym.

Założono, że przedsięwzięcie liniowe (droga, tunel, rurociąg itp.) powinno być podzielone na odcinki (działki robocze) o różnych długościach i pracochłonnościach robót. Procesy powtarzalne są wykonywane na każdej z tych działek. Dla 
każdego rodzaju procesu jest dokonywany dobór liczebności brygady roboczej lub liczby maszyn - skład tych brygad /zestawów maszyn jest niezmienny na każdej lokalizacji robót.

Relacje kolejnościowe między procesami na każdej działce roboczej są typu „rozpoczęcie po zakończeniu” z ustalonymi opóźnieniami. Zdefiniowana jest także kolejność zajmowania działek roboczych przez jednostki organizacyjne.

Postęp robót na działce określony jest według poczynionych wcześniej ustaleń (zgodnie z kilometrażem lub od końca sekcji do jej początku). Do realizacji każdego prosu są niezbędne zasoby odnawialne (np. pracownicy rożnych specjalności lub maszyny). Dla każdego procesu zdefiniowano zbiór wariantów organizacyjnych brygad lub zestawów maszyn. Każdy wariant organizacyjny jest opisany różną liczbą jednostek zasobów odnawialnych go tworzących. Przez cały okres planowania liczba dostępnych zasobów jest ograniczona. Wybór wariantu organizacyjnego jest modelowany za pomocą zmiennych binarnych. Na podstawie pracochłonności i wydajności brygad można określić czasy trwania wszystkich procesów na każdej działce roboczej dla każdego wariantu organizacyjnego.

Funkcja celu minimalizuje czas realizacji przedsięwzięcia. W terminie 0 rozpoczyna się realizacja procesu pierwszego rodzaju na pierwszej działce, na której będzie on wykonywany. Każdy proces musi zakończyć się na każdej działce roboczej nie później niż w określonym dla niego terminie dyrektywnym. Terminy rozpoczynania procesów są ustalane z uwzględnieniem kolejności technologicznej wykonania procesów, ustalonego postępu robót na działkach, dopuszczalnych opóźnień w rozpoczynaniu procesów oraz z uwzględnieniem kolejności zajmowania działek przez jednostki organizacyjne (zadanej w postaci permutacji dla każdego procesu). Powinien być spełniony warunek ciągłości pracy jednostek organizacyjnych. Zapotrzebowanie na zasoby każdego dnia realizacji nie może przekroczyć limitu ich dostępności. Dla każdego procesu musi być dokonany wybór dokładnie jednego wariantu organizacji brygady roboczej. W artykule wykorzystano programowanie liniowe całkowitoliczbowe do modelowania problemu harmonogramowania przedsięwzięć liniowych i przedstawiono przykład jego rozwiązania. W przykładzie model matematyczny problemu rozwiązano stosując program Lingo 14.0.

Opracowany model pozwala decydentowi na optymalną alokację ograniczonej liczby zasobów odnawialnych (brygad roboczych, sprzętu budowlanego) podczas realizacji przedsięwzięć liniowych. Model uwzględnia różną permutację kolejności działek, na których są wykonywane procesy. Jest to użyteczne np. podczas modelowania robót prowadzonych z różnych kierunków na harmonogramach dwuosiowych: czas - odległość (lokalizacja). W celu optymalizacji harmonogramów realizacji przedsięwzięć liniowych obejmujących niewielką liczbę procesów angażujących kilka rodzajów zasobów, można stosować dostępne na rynku solvery, umożliwiające rozwiązywanie opracowanego modelu programowania mieszanego programowania całkowitoliczbowego lub nieliniowego.

Dalsze badania autorów będą się koncentrowały na uwzględnieniu w modelu dodatkowych warunków i ograniczeń typowych dla przedsięwzięć liniowych np. efektu uczenia się, zmienności wydajności brygad roboczych, możliwości podzlecania robót, podzielności i przerywalności procesów. W celu umożliwienia rozwiązywania bardziej złożonych, praktycznych problemów harmonogramowania z mniejszym nakładem czasu obliczeń, autorzy zamierzają opracować komputerowy system wspomagania podejmowania decyzji z zastosowaniem algorytmu metaheurystcznego. 